$$
\begin{aligned}
& \text { 大規模電力系統シミュレータの開発 } \\
& \text { 正員土井宏祐 (関西電力) } \\
& \text { 正員後藤 益雄 (日立) } \\
& \text { 正員河合忠雄（日立） } \\
& \text { 正員鈴 木 智 宏 (富士電機) } \\
& \text { 正員横川純男 (富土電機) }
\end{aligned}
$$

\title{
Development of Advanced Power System Analogue Simulator
}

Hirosuke Doi, Member (Kansai Electric Power Co., Inc.), Masuo Goto, Member, Tadao Kawai, Member (Hitachi Ltd.), Tomohiro Suzuki, Member, Sumio Yokokawa, Member (Fuji Electric Corporate R \& D Ltd.)

The digital simulation method has been utilized to analyze phenomena in power system. Since different algorithms can be applied, depending on the phenomena to be analyzed, digital simulation allows for high-precision analysis.

However, it also has a disadvantages: it produces continuous phenomena which occur in actual systems only fragmentarily. Thus, when discussing important projects at research centers such as IREQ in Canada, use an analogue simulator to continuously analyze the phenomena from the moment the fault occurs until steady state.

These analogue simulators however, consists of only a few generator models. They are only effective for analyzing phenomena in small-scale systems and do not allow for analysis of phenomena in large-scale systems over a long period of time.

For this reason, the Kansai Electric Power Company (KEPCO) in coopration with Hitachi, Ltd. and Fuji Electric Co., Ltd, has developed the world's largest power system simulator (APSA: Advanced Power System Analyzer). The simulator will be used to analyze the evolution of accidents in actual systems and to analyze continuous system phenomena over long period.

This paper describes an outline of the simulator.

$$
\text { キーワード:電力系統シミュレータ,アナログシミュレータ, 自動結線装置, 発電機モデル }
$$

\section{1.まえがき}

ディジタル計算機の進展と共に電力系統の現象解析 には実効值ベースの安定度計算プロク゚ラムや EMTP などによるディジタルシミュレーションが多く用いら れてきた。ディジタルシミュレーションは解析対象と なる現象領域によって異なるアルゴリズムを適用する ため，それぞれの現象領域に㧍いて高精度の解析がで きる半面，実系統に発生する連続現象を断片的にしか 再現できない欠点ももっている。
このため，世界の重要ブロジェクトの検討には，事 故発生の瞬間から定常領域までの現象が連続して解析 できるアナログシミュレータが併用され，解析精度の 向上を図ると共に，予期せ好現象の発生の有無の推定 に役立てられている。

日本に扔いても, 電力中央研究所の大容量回転機形 $(100 \mathrm{kVA}, 3 \mathrm{kV})$ をはじめとする，アナログシミュ レータがその役割を担ってきた。世界に扔いても，力 ナダのIREQなどの研究機関扔よび各メーカーのア ナログシミュレータが活用されている(1)。 
しかしここ祊のアナログシミュレータは，いずれ も数機の発電機モデルによって構成されるシミュレー タであり，その機能を発揮できるのは小規模な系統の 現象解析に限られ，大規模な系統を対象とした解析で は多くの場合定性的な検討の域をでることができない のが実情である。

半面, 電力系統は大規模化, 複雑化の傾向をたどっ ておりより高い信頼度が要求されるようになってき ている。また，このような電力系統における系統構成 の適正化，信頼度向上のための制御技術の開発，新技 術を適用した新たな機器の導入など，数多くの技術課 題の検討が必要となってきている。

このような背景から, 関西電力では日立製作所と富 士電機の協力得て, 発電機モデル 30 台, 送電線モ デル 300 台をはじめとし，各種電力機器モデルを含め ると総数 500 ユニットを超える大規模なアナログ形の 電力系統シミュレータを開発製作した。完成したシミ ュレータは, 略称を APSA (Advanced Power System Analyzer) と称し, 数 $\mathrm{m}$ 秒の過渡現象加ら数十 分にわたる現象まで対応できる解析機能を有してお り, 電力系統に発生するほとんどの現象の解析が可能 である。

本論文では，APSAの開発技術と，実系統試験の 結果と比較した性能試験の一例について述べる。

\section{APSA の概要}

APSA 注図 1 に示す機器で構成されておりり六，その 定格は直列機器の損失と並列機器の負担および設置ス

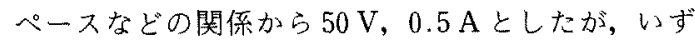
れも解析対象とする現象を考慮して $300 \mathrm{~V}, 5 \mathrm{~A}$ の最 大連続容量としてある。

APSAのように，極めて多数のユニットを使用し た大規模アナログシミュレー夕を実現する最も大きな 技術課題として，下記が挙げられる(3)(4)。

・ユニット単体の精度, 再現性の確保

・コンパクト化

- 結線, 操作の省力化

このため，APSAでは次の技術的対応策を取るこ とによって高性能なシミュレータを完成することがで きた。

・多数の夕イプの表現が可能な発電機モデルと負荷 モデルの開発

・低損失, 特性可変形の変圧器モデルと送電線モデ ルの開発

特に,アナログ形シミュレータの運用上最も重要な 課題は，設定作業や解析処理をいかに自動化・省力化

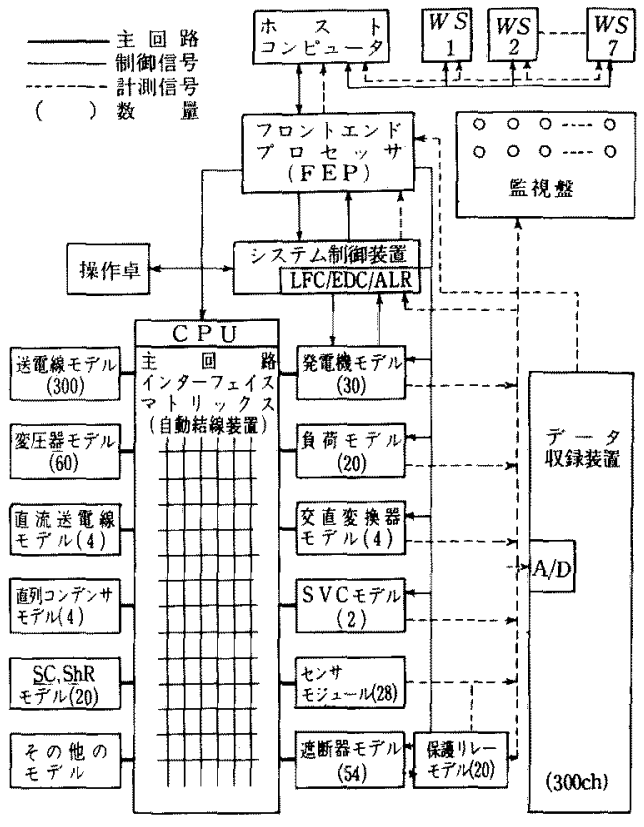

図 1 APSA の構成

Fig. 1. Construction of APSA.

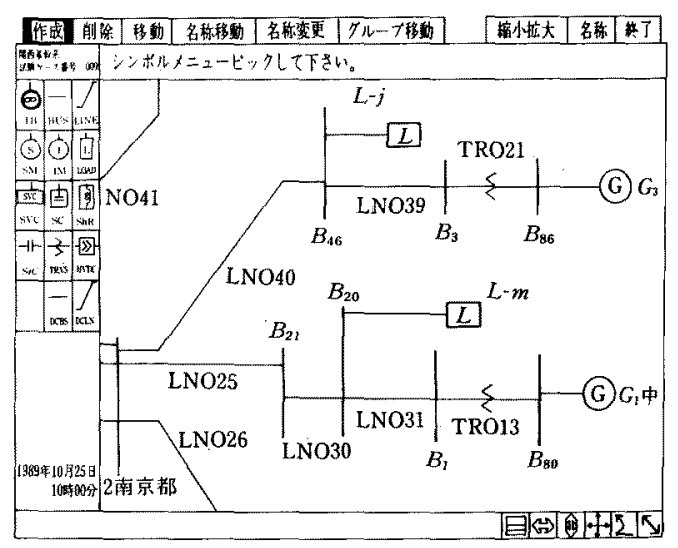

図 2 入力画面の例

Fig. 2. Example of input data for simulation.

できるかということにあり，APSAではこの点に最 大の腐心をはらい，次の 2 機能を開発した。

・高機能マン・マシン性を有するコンピュータ・サポ ートシステム

・系統構成を自動設定する自動結線システム

系統解析にあたって不可欠な, 系統構成の入力か ら，アナログ回路の構成までを上記 2 機能の採用によ って次のように自動化・省力化することができた。 
すべてのデータはワークステーションの画面より図 2のように図形の形で入力され，系統構成をホストコ ンピュータが認識し，シミュレーションが可能なモデ ルニニットの候補を選定する。自動結線用のCPU は，この候補の中から最も結線距離が短くなる個体を 決定し,シミュレーション回路を自動構成する。また 各機器モデル用の各定数は,フロントエンドプロセッ 少を介して各モデルへ伝送されシミュレーションに必 要な状態が完成する。

その他, 必要に応じて回路構成, 定数設定の状態が チェックできると共にシミュレーション中の状態の 監視から結果の分析まで，幅広くコンピュータのサポ 一トを受けて実行することが可能となった ${ }^{(5)(6) 。 ~}$

\section{APSA の開発技術}

高性能アナログ形電力系統シミュレータ APSA 実現するにあたり，新しく開発した技術について述心゙ る。開発した機器モデルの仕様と制御機能は次の三つ の条件をべースに構筑した(7)。

・電力系統機器モデルの特性が, 実機の特性に広範 囲に対応でさること

-電力系統現象が正確に表現され，かつ再現性を有 すること

・500ユニットに及ぶ大規模シミュレータが運転支

援システムにより効率的に運用されること

〈3・1〉 発電機モデル 電力系統解析で, 発電機 の挙動は最も重要な要因である。そのため発電機モデ ルは実機の物理特性により忠実な表現，および高い模 擬精度が要求される。このような観点から次のような 基本仕様を決めたた ${ }^{(8)(9)}$ 。

・発電機の諸定数などはワークステーションから自 由に選定できる

- 発電機本体特性は同期機, 誘導機, 可変速機のい ずれにでも選択変更できる

・軸的じれ共振, 過渡なじれトルクの解析のため 4 質点の軸系モデルを設ける

・励磁系, 調速系, タービン系はマイクロコンピュ 一タで多種の特性に対応可能とする

発電機本体络同期機, 誘導機, 可変速機などの夕夕 プ変更用のディジタル演算形(15台) と，高い周波数 領域の解析用のアナログ演算形（15台）の2 機種を 開発した。いずれもAVR，GOVの制御系はディジタ ル演算のため, 前者をディジタル形, 後者をハイブリッ ド形と称する。

図 3 がディジタル形発電機モデルの構成図で出力增 幅器を介してアナログ系統に接続される。

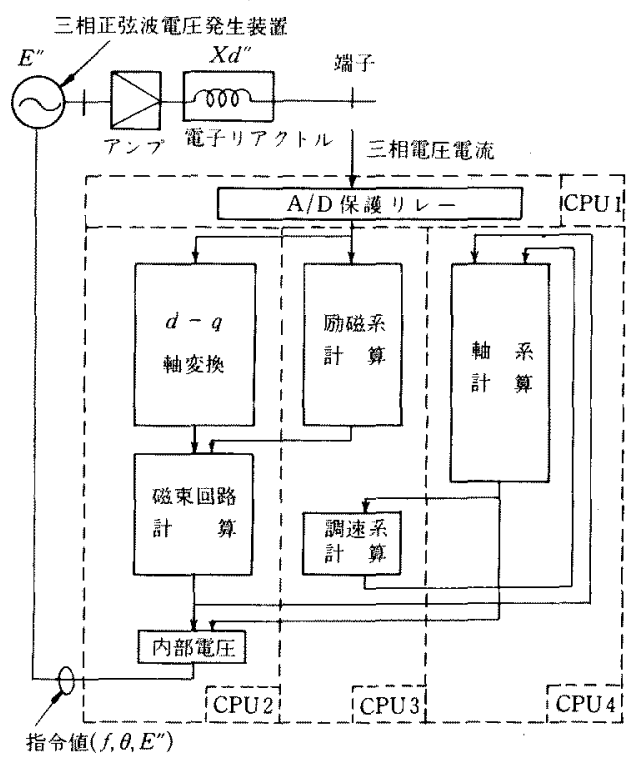

図 3 ディジタル発電機モデルの構成 Fig. 3. Construction of digital type generator model.

いずれの発電機モデルも(1)式朽よび (2)式で表さ れるパークモデルを採用し、ディジタル発電機モデル ではタイプ変更用として, 誘導機モデルの $(3)$ 式扝よ び可変速モデルの(4)式も採用した ${ }^{(10)}$ 。

同期機の方程式

電圧, 電流に関して,

$$
\left.\begin{array}{l}
P \Psi_{d}=e_{d}+\Psi_{q} \omega+r_{a} i_{d d} \\
P \Psi_{q}=e_{q}-\Psi_{d} \omega+r_{a} i_{q} \\
P \Psi_{f d}=e_{f d}+r_{f d} i_{f d}, P \Psi_{1 d}=-r_{1 d} i_{1 d} \\
P \Psi_{1 q}=-r_{1 q} i_{1 q}, T e=\Psi_{d} i_{q}-\Psi_{q} i_{d}
\end{array}\right\}
$$

運動方程式に関して,

$$
\left.\begin{array}{l}
p \delta=\Delta \omega \\
p \Delta \omega=\frac{\omega_{0}}{M}\left\{T m-\left(\Psi_{d} i_{q}-\Psi_{q} i_{d}\right)\right\}
\end{array}\right\}
$$

誘導機の方程式

$$
\left.\begin{array}{l}
p \Psi_{d}=e_{d}+\Psi_{q} \omega+r_{1} i_{d} \\
p \Psi_{q}=e_{q}-\Psi_{d} \omega+r_{1} i_{q} \\
p \lambda_{d}=-r_{2} i_{r d}+\lambda_{q} S \\
p \lambda_{q}=-r_{2} i_{r q}-\lambda_{d} S \\
T e=\lambda_{d} i_{r q}-\lambda_{q} i_{r d}
\end{array}\right\}
$$

可変速機の方程式 


$$
\left.\begin{array}{l}
p \Psi_{d}=e_{d}+\Psi_{q} \omega+r_{a} i_{d} \\
p \Psi_{q}=e_{q}-\Psi_{d} \omega+r_{a} i_{q} \\
p \Psi_{f d}=e_{f d}+r_{f d} i_{f d} \\
p \Psi_{f q}=i_{f q}+r_{f q} i_{f q} \\
T e=\Psi_{d} i_{q}-\Psi_{q} i_{d}
\end{array}\right\}
$$

特に，ディジタル形ではアナログシミュレータに用い る発電機モデルとして実時間性が要求されるため，従 来 $20 \mathrm{~m}$ 秒程度必要としていた計算時間を, 図 4 に示 す上うに 4 台の $\mu \mathrm{CPU}$ による並列演算を採用し，約 $1.4 \mathrm{~m}$ 秒と実系統に使用している,ディジタル形保護り レーのサンプリングレート並みに短縮している(11)。 文献(11)では本手法の原形を報告している。本システ ムでは軸トルク演算や制御系の詳細ブロック演算を新 たに取入れたため，32ビットCPUやDSPを使用し

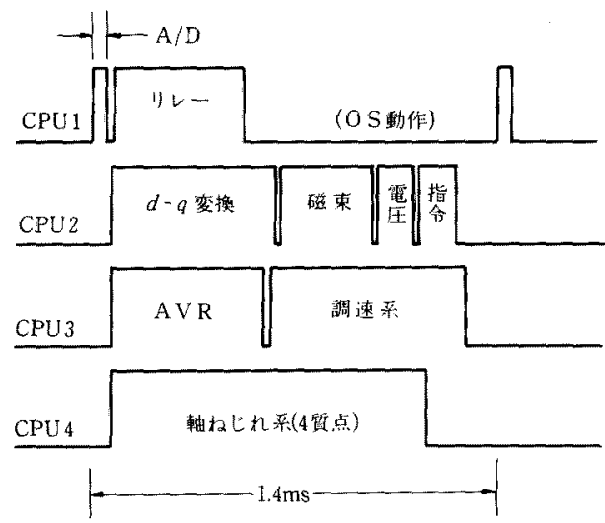

図 $4 \mu \mathrm{Pc}$ の演算時間の測定結果

Fig. 4. Measurement of operation time on micro processer.
て，処理速度を文献(11)に比べて更に向上させて いる。

また，八イブリッド形では従来アナログ演算回路の 欠点であった定数設定の再現性困難を解消するため， 図 5 k示すような自動定数設定回路を付加した。一般 に高㷌還增幅器の帰還抵抗などを離れた構造にすると 回路の安定性に問題がでることが多く, APSA でも 同様の問題が発生したが，アナログ基板のレイアウト を工夫することと, 発振防止・ドリフト減少などの安 定化回路を付加することで解決することができた。

〈3.2〉負荷モデル 電力系統の過渡現象や動特 性を解析する場合, 負荷特性の表現も重要である。特 に, 系統の周波数および電圧に依存する特性が非常に 重要となる ${ }^{(12)(13) 。}$

APSAの負荷モデルは，図6の構成になっており， 主幹系統の一変電所加ら眺媓魵荷特性を表現するこ とが多いため，周波数および電圧特性だけでなく系統 保護りレーなどからの制御動作および負荷自身が系統

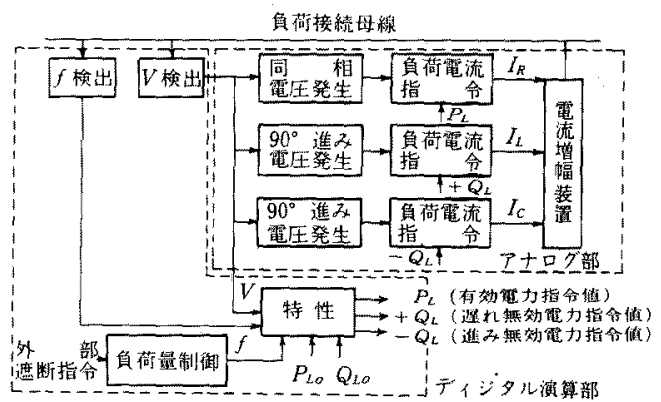

図 6 負荷モデルの構成

Fig. 6. Construction of Ioad mocel.

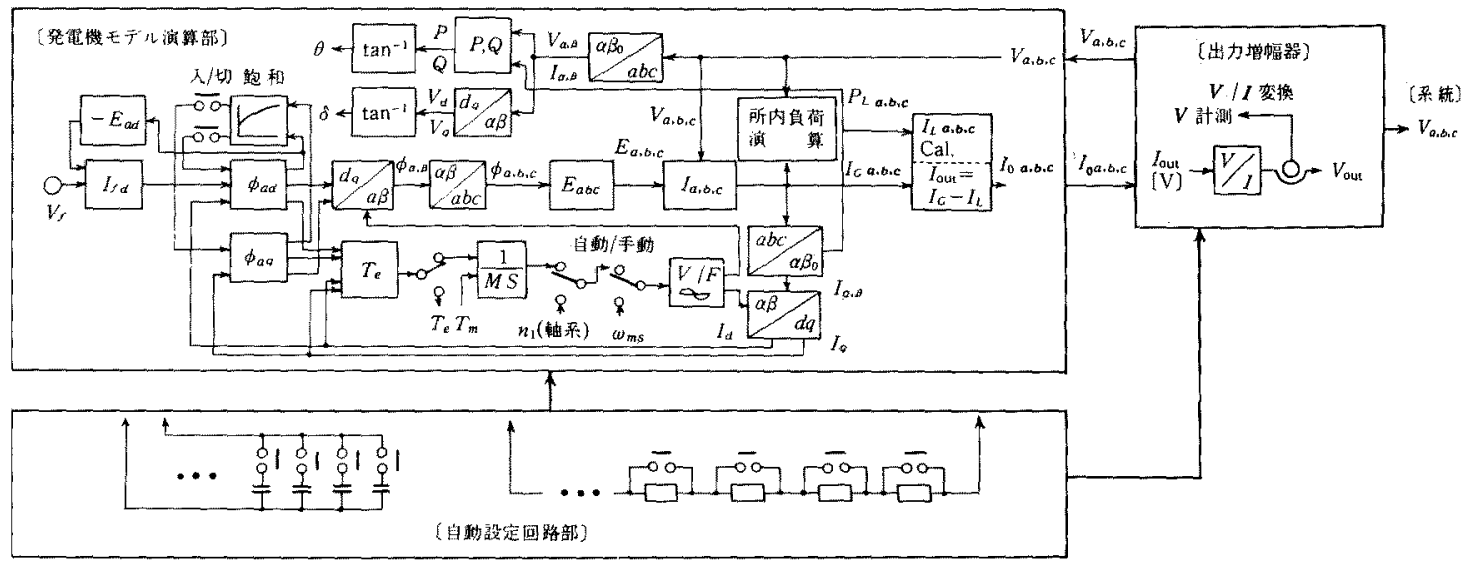

図 5 ハイブリッド発電機モデルの構成

Fig. 5. Construction of hybrid type generator model. 


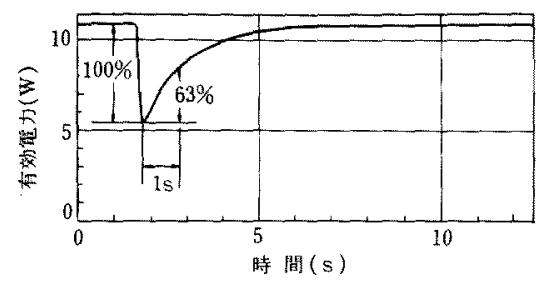

$$
\begin{aligned}
& I_{0}=0.125 \mathrm{~A} \quad \text { : 定格㲠流(毛デル定格) } \\
& V_{0}=50.0 \mathrm{~V}: \text { : 定教電生 } \\
& I_{\text {rax }}=0.250 \mathrm{~A} \quad \text { : 舅大出力籍流 } \\
& \alpha=0.0 \quad: \text { 䔩圧特性指数 } \\
& \beta=0.0 \quad \text { : 電圧特性指数 } \\
& P_{L 0}=10.825 W(1.0 \mathrm{pu}): \text { 南効電力 初期値 } \\
& Q_{L O}=5.413 \text { Var }(0.5 \mathrm{pu}) \text { : 典効電力 初期值 } \\
& T_{P_{1}}=1.00 \mathrm{~s} \\
& T_{p_{2}}=0.00 \mathrm{~s}
\end{aligned}
$$

図 7 觬荷モデルの電圧変動に対する動特性

Fig. 7. Dynamic characteristic of load model.

のじよう乱原因となる場合のシミュレーション用とし て，任意の負荷変動も発生できるようにしてある。

負荷特性注周波数の静特性おるよ゙電压の静・動特性

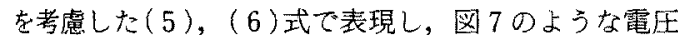
急変時の負荷の瞬時変化量や回復速度が表現できるも デルとなっている(14)。

またこれらの特性定数扝よび連用条件は，すべて ワークステーションからの遠䧣設定が可能である。

$$
\begin{aligned}
P_{L}= & V_{L}^{2} \frac{P_{L 0}}{V_{L 0}^{2}} \frac{1+T_{p 2} S}{1+T_{p 1} S}\left(\frac{V_{L}}{V_{L 0}}\right)^{\alpha-2} \\
& +P_{L 0}\left(\frac{V_{L}}{V_{L 0}}\right)^{\alpha} K_{p} \Delta f \cdots \ldots \ldots \ldots \ldots \\
Q_{L}= & V_{L}^{2} \frac{Q_{L 0}}{V_{L 0}^{2}} \frac{1+T_{Q 2} S}{1+T_{Q 1} S}\left(\frac{V_{L}}{V_{L 0}}\right)^{\beta-2} \\
& +Q_{L 0}\left(\frac{V_{L}}{V_{L 0}}\right)^{\beta} K_{Q} \Delta f \cdots \ldots \ldots \ldots \ldots
\end{aligned}
$$

〈3.3〉变圧器モテル＼cjkstart縮小形変圧器モデルは, 電力系統解析において過渡現象の減衰特性，励磁特 性，飽和特性の奏機に対する等価性が重要である。図 8 が変圧器モデルの構成で, 理想変圧器と電圧タップ および漏れりアクタンスを表現する外付けのリアクタ で構成している。奏機並みの特性とするために次のよ うな特長を有している。

・損失と劯磁電流を極力小さくするため，理想変压 器の鉄心材料にパーマロイを使用すると共に環状 鉄心楧造を採用した。

・斺磁特性および飽和特性を可変とするために，変 圧比一定の一次・二次連動の飽和開始電圧設定夕 ップを設けた。

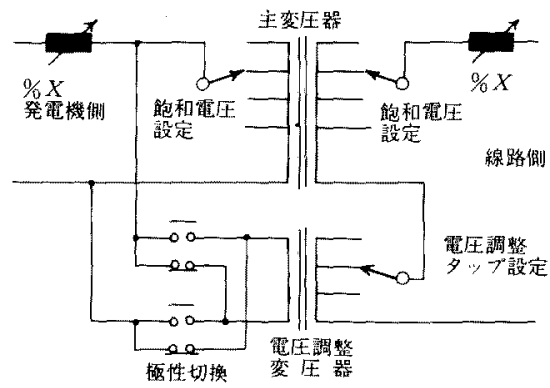

図 8 変圧器モデルの構成 (1相分)

Fig. 8. Construction of transformer model (single phase component).

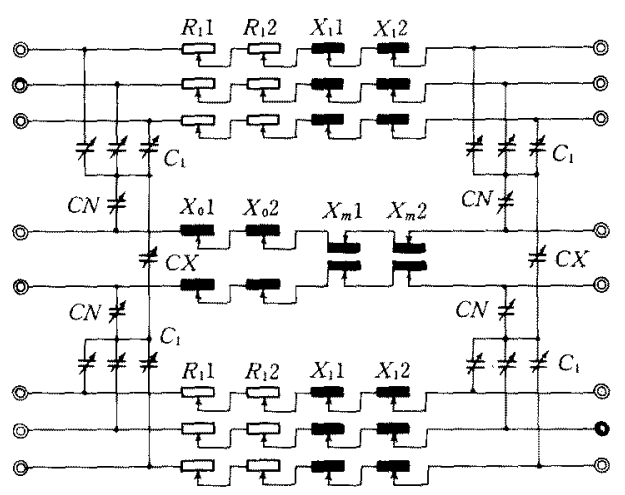

図 9 送電線モデルの構成

Fig. 9. Construction of transmission line model.

・定電死自動運転を可能にするた方，不感带および 動作速度が設定できる負荷時切換えタップを設け to

これにより，特性が可変で低損失・低励磁電流の電 圧制御機能有ずる変圧器モデルが夷現できだ

〈3・4〉送電線モデル 送電線モデルは，実際の 送電線に近い特性を実現することが重要である。図 9 が送電線モデルの構成の一例で全受動素子で, 直列イ ンピーダンスから自回線内扔よび回線間の静電結含・ 電磁結合まで表現している。

送電線としての等価性を保つため次の基本仕様を設 定した。

- $500 \mathrm{kV}$ 送電線の $810 \mathrm{~mm}^{2} \times 4$ 導体並みの低損失を 確保するため $60 \mathrm{~Hz} て ゙ の Q(=\omega L / R)$ を 30 以上 とする

・定格電流の $1,000 \%$ 電流でも飽和しない

・定格電压の $600 \%$ 過電圧耐量を有する

・リアクタンス愦差を $1 \mathrm{kHz}$ で $1 \%$ 以下にする 300 ユニットにおよら゙送電線无デルを限られたスぺ 
表 1 送電用モデル用鉄心材料と特性

Table 1. Transmissionline model core and characteristie.

\begin{tabular}{c|c|c|c|c|c}
\hline 比較 \\
䥊目
\end{tabular}

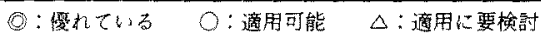
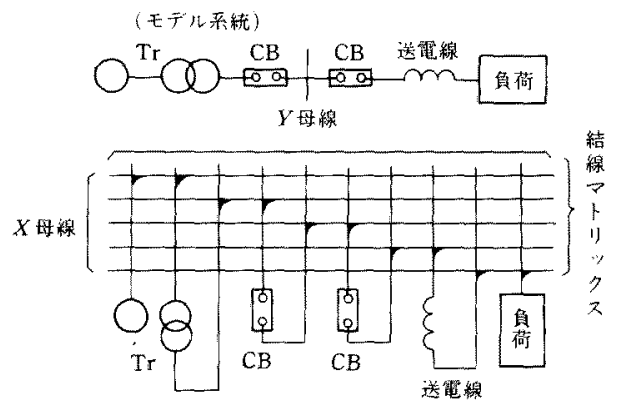

図 10 自動結線の概念

Fig. 10. Concept of automatic network configuration by matrix array switch.

一スに設置するには，鉄心入りのリアクトルを使用せ ざる在得ない。鉄心材料としては表 1 に示すように特 性的にフェライトが適しているが，磁束密度が低く物 䥣の低隇としては逆効果となる。そこでケイ素鋼板を 薄くすることで特性向上を図り, 結果的には累さ $0.05 \mathrm{~mm}$ でぼ目的の特性を達成することができ た

〈3.5〉自動結線システム 500 ユニットを超え るAPSAを手動により任意の系統構成に接続するこ とは不可能に近く，今まで，大規模なアナログシミュ レータの実現を見なかつた要因の一つでもある。

このなめAPSAでは，図 10 に示すような自動結線 システムを採用し，回路構成の省力化を图った ${ }^{(16)}$ 。

図 10 は，自動結線システムのハードウェアの概念 で，各モデルユニットの端子に接続された接続りレー のマトリックスの交点を選択接続することで, 任意の 系統構成を作成することが可能である。

しかし，500ユニットのモデルの両端子を自由に接 続させようとすると，500×500で25万点の交点をも ったマトリックスを設ける必要があり，これも奏現性

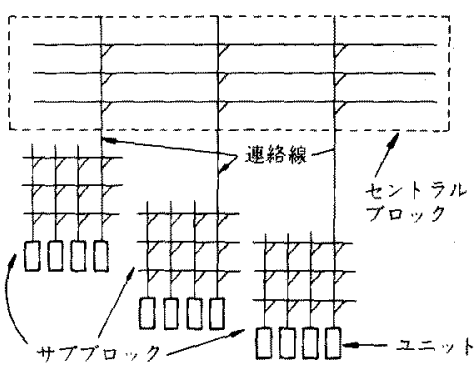

困 11 階層形マトリックス結線方式 Fig. 11. Matrix switching method for hierarchal system.

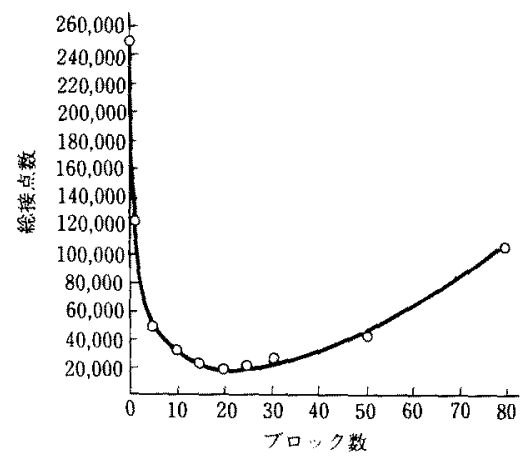

図 12 総接点数とブロック数の関係 (500ユニット時)

Fig. 12. Relationship of no. of total switchs between no. of sub-block systems (at 500 units).

の面で問題がある。そこでAPSAでは図11のよう に，大規模マトリック又の対角湎付近を切り出した小 マトリックス (サブブロッタ) と，このサブマトリッ クス間を結ぶ補助マトリックス(セントラルブロッ ク）に分割した階層形マトリックス方式を採用し，総 接点数の低隇を図った。

階層形マトリックス方式を採用する場合に重要なの はサブブロック数の選び方で，図 12 に示すようにサ プブロック内の合計接点数は分割数が多いほど減少す るが, セントラルブロック内の接点数は增加し，総接 点数は途中から増加することになる。APSAでは絤

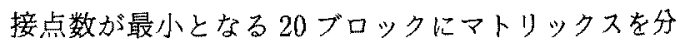
割すると共に，送電線のように極性をもたないユニッ トの片端子を固定結線することにより，約 9,000 点の 交点のマトリックスで自動結線用マトリックスを構成 Lた。

幸いにも，電力系統は比較的放射状の構成に近く， このような簡略化を行っても結線の目由度は，あまり 
制約を受けることはない。

\section{4. 総合特性試験結果}

APSAの基本的な特性試験と奏系統試験結果との 対比試験結果の例をいくつか以下に述べる(17)。

〈4・1〉軸ねじれトルク発電機モデルは，前述 の (2) 式の運動方程式を(7) 式に置換えることによっ て，4質点の軸系模擬できる機能を有している。

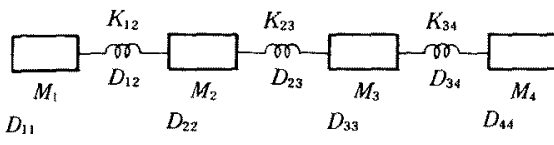

$$
\begin{aligned}
& M_{1} p^{2} \delta_{1}+D_{12} p\left(\delta_{1}-\delta_{2}\right)+K_{12}\left(\delta_{1}-\delta_{2}\right) \\
&+D_{11} p \delta_{1} \\
&= T m_{1} \\
& M_{2} p^{2} \delta_{2}+D_{23} p\left(\delta_{2}-\delta_{3}\right)+D_{21} p\left(\delta_{2}-\delta_{1}\right) \\
& \quad+K_{23}\left(\delta_{2}-\delta_{3}\right)+K_{21}\left(\delta_{2}-\delta_{1}\right)+D_{22} p \delta_{2} \\
&=T m_{2} \\
& M_{3} p^{2} \delta_{3}+D_{34} p\left(\delta_{3}-\delta_{4}\right)+D_{32} p\left(\delta_{3}-\delta_{2}\right) \\
& \quad+K_{34}\left(\delta_{3}-\delta_{4}\right)+K_{32}\left(\delta_{3}-\delta_{2}\right)+D_{33} p \delta_{3} \\
&=T m_{3} \\
& M_{4} p^{2} \delta_{4}+D_{43} p\left(\delta_{4}-\delta_{3}\right)+K_{43}\left(\delta_{4}-\delta_{3}\right) \\
& \quad+D_{44} p \delta_{4} \\
&=T m_{4}
\end{aligned}
$$

図 13 は, 全負荷遮断時の軸的じれトルクのシミュ レーション結果でEMTPによる計算結果ともよく一 致しており，モデル化の正確さが检証されている(18)。

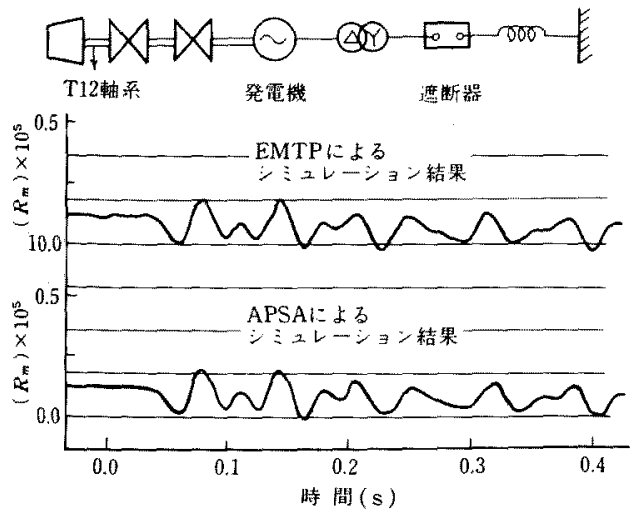

図 13 全負荷遮断時の軸ねじれトルクの 比較

Fig. 13. Comparison of shaft torsional torque at shut down on full power operation.

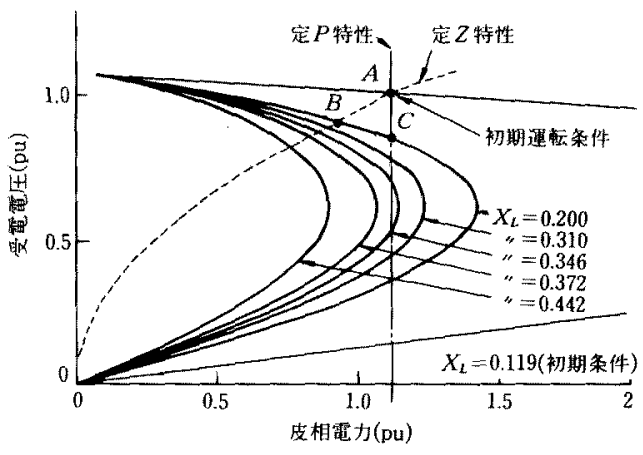

図 14 負荷の電圧・電力特性

Fig. 14. Voltage characteristic of load power.

〈4・2〉電任安定性 電力系統に求ける鱼荷の消 費電力 $(S)$ と受電端電圧 $\left(V_{r}\right)$ の)関係は, $(8)$ 式の関 係で表される。この関係を送受電端間のリアクタンス $\left(X_{L}\right)$ をラ゚ラータとしたグラフで表すと図 14 と なる。

$$
\begin{aligned}
& S^{2} \pm 2 S \sqrt{1-P_{f}^{2}}\left(\frac{1}{X_{L}}-Y_{C}\right) V_{r}^{2} \\
& \quad+\left(\frac{1}{X_{L}}-Y_{C}\right)^{2} V_{r}^{4}-\left(\frac{V_{S} V_{r}}{X_{L}}\right)^{2}=0
\end{aligned}
$$

$S$ : 皮相電力, $P_{S}$ : 力率, $Y_{C}$ : 補償コンデ ンサ, $V_{S}$ : 送電端電圧，士は $Q_{L}$ の符号と対 応する

図 14 において，A点で運転中の負荷の電源と負荷 を結ぶりアクタンスを增加させると，定インピーダン 又負荷の場合は $B$ 点に, 定電力負荷の場合は $C$ 点に 運転点が移動することになる。もし定電力䝿荷におい て C 点が存在しないほどリアクタンスを増加させる と，受電電压は限りなく低下してしまうことになる。 これが電㽵安定性の中で言うところの電圧崩壇現象で ある。

今回, 急荷モデルを用いてこの現象を定電力負荷に ついてシミェレーションしてみたのが図15および図 16 でる。図 15 は C点が存在する場合で, 電流が 増加し電圧が低下しても一定値に落着き, 電力も安定 化している安定なケースである。

図 16 は C点が存在しないはど大幅にリアクタンス を增加させた場合で，電流の増加と共に電压も低下し 電力の回復できない不安定なケースである。

このように, APSAの負荷モデルは電圧安定性の 解析にも十分使用できることが検証された。

〈4·3〉実系統試験結果との比較 性能検証試験 
$\left(X_{L}: 0.119 \rightarrow 200 \mathrm{pu}\right)$

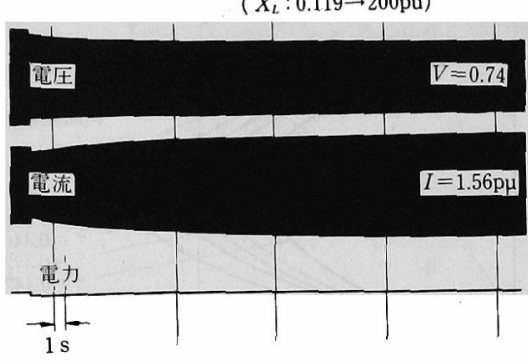

図 15 電圧安定性の試験結果 (安定なケース)

Fig. 15. Test results of voltage stability (stable case).

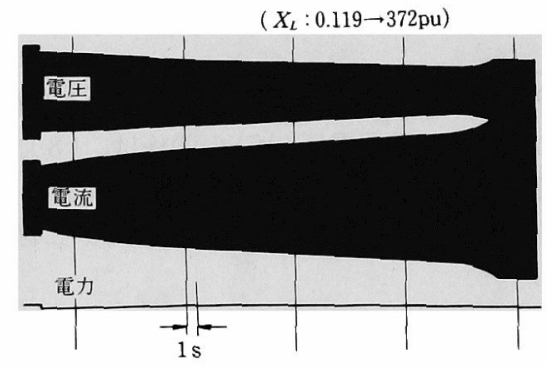

図 16 電圧安定性の試験結果 (不安定なケース)

Fig. 16. Test results of voltage stability (unstable case).

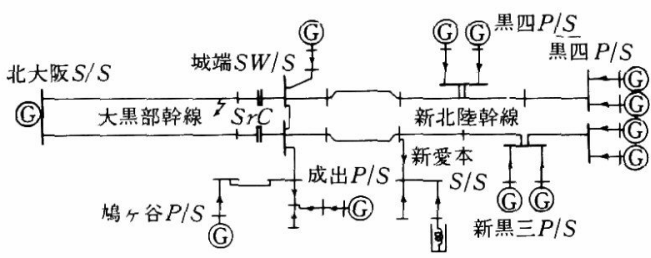

図 17 試験系統

Fig. 17. Field tested power system.

(最大周期 $1.18 \mathrm{~s}$, 最大振幅 4.6 MW)

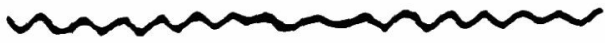

（a）実系統試験結果

(最大周期 $1.06 \mathrm{~s}$ ，最大振幅 7.9 MW)

(b) APSAによる実験結果

図 18 安定度限界付近の電力動摇の比較

Fig. 18. Comparison of power swing at stability limit.
の一つとして, 昭和 48 年 10 月に関西電力の大黒部幹 線 $(275 \mathrm{kV}, 244 \mathrm{~km})$ に補償度 $22 \%$ の直列コンデン サを設置したときに実施した送電容量試験および人工 故障試験の再現を APSA を用いてシミュレーション した。このときの試験系統を図 17 に示した。

実系統では, 黒四 P/Sの発電機出力が各々 $0.8 \sim 0.85 \mathrm{pu}$ でほほ連続動摇状態となったので,こ の断面を実測と APSA のシミュレーションと比較し たのが図 18 である。この結果，シミュレーションの ほうが若干動摇周期が短く，振幅も大きくなっている が，動摇状況はいずれも安定限界の様相を示してお り,この後若干の出力増加により発散傾向の不安定と なることから, 送電容量限界を見る安定度試験シミュ レーションとしては十分に実用的な結果を現している ものと判断される。

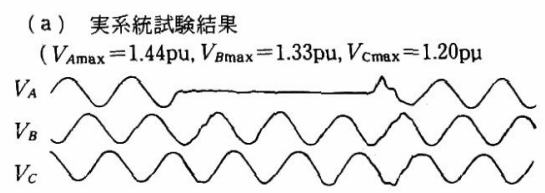

(b) APSAによる実験結果

$\left(V_{A \max }=1.45 \mathrm{pu}, V_{B \max }=1.33 \mathrm{pu}, V_{C \max }=1.20 \mathrm{pu}\right)$
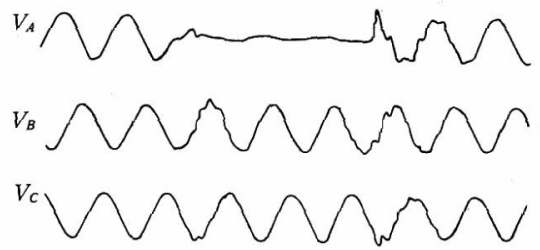

（1）城端 $S / S$ 母線電圧

(a) 実系統試験結果 $\left(I_{A \max }=3.00 \mathrm{pu}\right)$

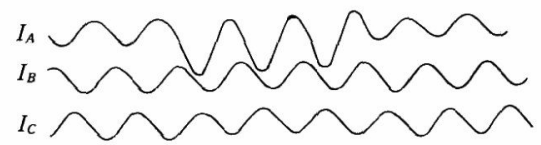

(b) APSA による実験結果 $\left(I_{\text {Amax }}=3.08 \mathrm{pu}\right)$ $I_{A} \backsim \mathrm{CONOCOCOCO}$<smiles>[3H]CCCCCCCCCCCCCCCCC</smiles><smiles>CCCCCCCCCCCCCCCCCC</smiles>

(2) 新黒 $=P / S$. 城端 $S / S$ 間線路電流

図 19 事故時電圧・電流波形の比較 ( $A$ 相 1 線地絡事故)

Fig. 19 Comparison of measured results on field test vs. simulated by APSA (one line ground fault at phase $A$ ). 
実系統における人工故障試験ケースの中から逆相・ 零相回路の等価性まで確認できるケースとして, 城端 $\mathrm{SW} / \mathrm{S}$ の直列コンデンサ至近端での一回線 $A$ 相地絡 故障を選定した。

この実測とシミュレーション結果を比較したのが， 図19である。

シミュレーション結果の波形から APSA の故障発 生位相の制御および遮断器モデルの電流零点における 開放機能が正しく動作していることが判断できる。

また, 電圧・電流の過渡変化值も実測の数\%程度の 差で再現されており，実測時の測定誤差を考慮すると ほほ完全な再現シミュレーションが行われたことがわ かる。

\section{5.むすび}

今回開発した大規模電力系統用のアナログシミュレ 一夕（APSA）の概要から，その開発技術および性能 試験結果の一部について記述したが，性能試験につい ては，まだ試験の必要な項目を多く残している。

関西電力では平成元年度末までかけて, 過去にバッ クデータの整っている系統試験の再現試験などを行 い, システムの総合的な性能を十分把握したうえで， 平成 2 年度より本格運用に入る計画である。

また, APSAの開発については, 各大学の先生方 および電力中央研究所の方々をはじめ, 数多くの方々 の助言をいただき，本日の完成を迎えることができま したので,ここに謝意を表します。

(平成元年 11 月 13 日受付)

\section{文献}

(1) Laurie Snider, "The Power System Simulator Complex at IREQ", Congress paper, 7th COPIMERA (1977) Santiago

（2）沖・西森・吉田・土井・後藤・横川: 「高性能系統解析試娩 装置心摡要」, 昭 62 電気関倸学会関西支部連大, No. G 4 - 1

（3）沖・森岡・河合・永倉・横川・鉿木：「大規模アナログ電力 系統シミュレータの開発(その1・設備概要と技術課題) 」, 昭 63 電気学会全大, No. 927

（4）土井・沖・後藤・横川：「大規模アナログシミュレータの高 性能化に対する技術課題について」, 昭 62 電気学会電力技術 研会. PE- $87-103$

（5）竹中・田中・谷口・長尾・森岡・吉田・福本・沖：「高性能 系統解析試験装置の連転支援プログラムの開発」、昭 63 電気 学会電力技術研会, PE-88-86

（6）森岡・吉田・島村・中村・佐藤・湯谷：「大規模アナロダシ ミュレータの運用システム」, 平元電気学会電力技術研会, PE $-89-117$

(7) 沖・吉田・土井・河合・横川：「大規模アナログシミュレータ 门開発(その1) 一技術課題と対応策一」. 昭 63 電気学会電力 技術研会. PE- $88-83$

（8）西森・須崎・小海・後藤・銷木・沢里：「大規模アナログ電 力系統シミュレータの開発(各の $2 \cdot$ 発電機ユニット)」.昭 63 電父学会全大, No. 928
（9）福本・森岡・後藤・野原・小海・鈴木・富呮：「大規模了十 ログンミュレータの開発(その2)一発電機・負荷モデルー」, 昭 63 電気学会電力技術研会, PE- $88-84$

（10）土井・森岡・後藤・野原・影山：「大規模アナログシミュレ 一タ用ディジタル形発電機ユニット一誘導機・可変速機模擬 についてー」, 平元電気学会全大, No. 968

(11) Y. Kokai, I. Matori \& J. Kawakami: "Muitiprocesser Based Generator Module for a Real-time Power System Simulator", 88WM 181-O presented at the IEEE/PES 1988 Winter Meeting, New York (1988)

（12）広部・須崎・中西・富沢：「高性能系統解析試験装置用ディ ジタル形負荷モデル」, 昭 62 電気関係学会関西支部連大. No . G 4-2

（13）福本・森岡・後藤・野原：「高性能系統解析試験装置用八人 ブリッド演算形負荷モデル」, 昭 62 電気関倸学会関西支部連 大 No. G 4-3

（14）福本・吉田・野原・後藤・中西・富沢：「大規模アナログ電 力系統シミュレータの開発(その $3 \cdot$ 負荷ュニット)」, 昭 63 電気学会全大, No. 929

（15）広部・須崎・久和・西・斎藤・中西：「大規模アナログシミ ンレータの開発(その3) 一変圧器・送電線モデルー」, 昭 63 電気学会電力技術研会, PE- $88-85$

（16）広部・土井・佐藤・竹内・中村・河合：「大規模アナログ電 力系統シミュレータの開発(その4・自動結線システム)」, 昭 63 電気学会全大, No. 930

（17）須崎・土井・後藤・久和・鈴木・今村：「大規模アナログシ ミュレータ構成ユニットの特性」, 平元電気学会電力技術研 会, PE-89-116

（18）須崎・土井・小海・真鳥・後藤：「大規模アナログシミュレ 一タ用ディジタル形発電機ユニット一軸系模擬についてー」, 平1電気学会全大, No. 967

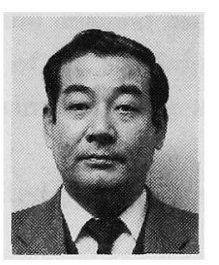

\section{土井宏 祐 (正員)}

昭和 20 年 2 月 13 日生。 40 年 3 月大阪府立今宮工業高校電気科卒 業。同年 4 月関西電力 (株) 入社。配 電系統の設計業務㧍よび系統運用計 画業務に従事。45 55 年, 㧍よび 60 年度以降は同社総 合技術研究所において電力系統解析, 制御の研究に従 事。IEEE 会員。

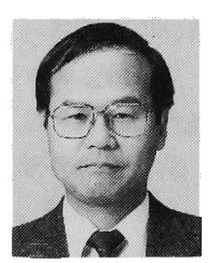

後 藤 益 雄 (正員)

昭和 17 年 5 月 9 日生。 40 年 3 月 大阪府立大学工学部電気工学科卒 業。同年 4 月(株) 日立製作所入社。 工学博士。同社日立研究所にて電力 系統の解析, 制御の研究に従事。6 1 年より同社国分工 場にて, 主として電力系統解析業務を担当。 45 年度才 一ム技術賞受賞。IEEE 会員。 


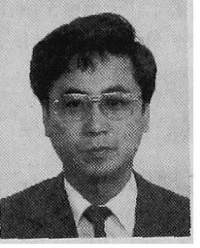

\section{河 合 忠 雄（正員）}

昭和 23 年 9 月 21 日生。 46 年 3 月東北大学工学部電子工学科卒業。 同年 4 月(株) 日立製作所入社。現在 同社国分工場送変電システム設計部 に所属。主として電力系統用制御保護装置および SVC, HVDC システムの開発に従事。63 年度電気学 会進歩賞受賞。

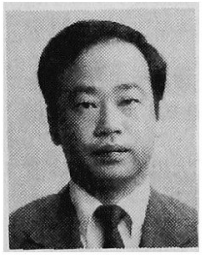

$$
\text { 鈴木智宏 (正員) }
$$

昭和 28 年 12 月 22 日生。 54 年 3 月早稲田大学大学院理工学研究科電 気工学専攻修士課程修了。同年 4 月 富士電機(株)入社。主として,電力系
統の解析，制御・監視装置の研究開発に従事。現在, 総合研究所系統制御技術開発部に勤務。

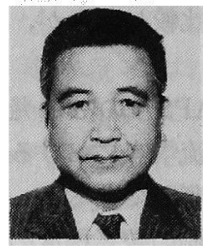

横川純男 (正員)

昭和 8 年 5 月 5 日生。 33 年早稲 田大学理工学部電気工業科卒業。同 年 4 月富士電機 (株)入社。現在総合 研究所系統制御技術開発部に勤務。 この間，主として電力系統制御システムの企画設計と 開発に從事。5 4 年度オーム技術賞受賞。IEEE 会員。 